\title{
SCIDiC
}

\author{
International Journal of Dentistry and Oral Science (IJDOS) \\ ISSN: 2377-8075
}

\section{The Prevalence Of Gingival Recession Among Different Types Of Malocclusion}

Research Article

Gayathri R Menon ${ }^{1}$, Sankari Malaiappan ${ }^{2 *}$, Kiran Kumar Pandurangan ${ }^{3}$

${ }^{1}$ Saveetha Dental College and Hospitals, Saveetha Institute of Medical and Technical Sciences (SIMATS), Saveetha University, Chennai - 600077 , India

${ }^{2}$ Professor, Department of Periodontics, Saveetha Dental College and Hospitals, Saveetha Institute of Medical and Technical Sciences (SIMATS),

Saveetha University, Chennai - 600 077, India.

${ }^{3}$ Senior Lecturer, Department of Periodontics, Saveetha Dental College and Hospitals, Saveetha Institute of Medical and Technical Sciences (SIMATS), Saveetha University, Chennai - 600 077, India.

Abstract

Gingival recession is one of the most common esthetic and undesirable problems that causes distress among individuals of all ages. Identifying and diagnosing such common clinical entities at an early stage helps to restrict its progression through preventive methods. The aim of the study is to assess the prevalence of gingival recession among different types of malocclusion. It was a retrospective study of patients reporting to Saveetha Dental College And Hospitals, Chennai for various treatments. Data was obtained from the patients records. Data extraction was done and was segregated based on 1) age 2) gender 3) types of malocclusion 4) Recession 5) Site. After data collection statistical analysis was done in IBM SPSS software. In this present study $67.9 \%$ of males and $32.1 \%$ of females with recession had malocclusion. The most common age group that was affected was 31-35 years. The most common type of malocclusion present in recession patients was Class II Div 1. From the chi square test performed for analysis of statistical significance between the site of recession and type of malocclusion it was found there is a negative correlation. The $\mathrm{p}$ value was $.444(\mathrm{p}>0.05)$. The chi square test performed to determine the correlation between recession site and gender, it was found that maximum recession was seen in the anterior teeth of male patients. $P$ value was 0.051 ( $\mathrm{p}<0.05$ ), statistically significant. Within the limits of the present study it can be concluded that the most common age group affected was 31-35 years. Male gender was most commonly affected. The most common type of malocclusion with recession was class II div 1.

Keywords: Anterior Teeth; Gingival Recession; Malocclusion; Recession; Types Of Malocclusion.

\section{Introduction}

Periodontitis is an inflammatory disorder of the periodontium which is caused by the destruction of periodontal tissues namely the PDL, cementum, alveolar bone, and gingiva. Periodontal disease includes both gingivitis and periodontitis. Gingivitis which is caused due to bacterial plaque accumulation is considered as the key risk factor for the onset of periodontitis. Plaque does not just contain bacteria but it also contains viruses which can cause disease progression [1]. Tumor necrosis factor-alpha is an important proinflammatory mediator that causes destruction of periodontal tissues [2]. Similarly in a recent study it has been reported the association between Interleukin-21 levels with periodontitis [3]. ET-1 has also been identified in periodontal diseases [4, 5]. Periodontitis can be associated with various systemic conditions [6]. The features of periodontitis are gingival enlargement, bleeding on probing, clinical attachment loss, gingival recession ,mobility of teeth and furcation involvement. One of the most common esthetic concerns among the patients is associated with gingival recession. Gingival recession is the exposure of the root surface due to migration of the gingival margin apical to the cementoenamel junction. It may be localised or generalised and can be associated with one or more tooth surfaces [7]. Gingival recession has several clinical consequences, including esthetic compromise,

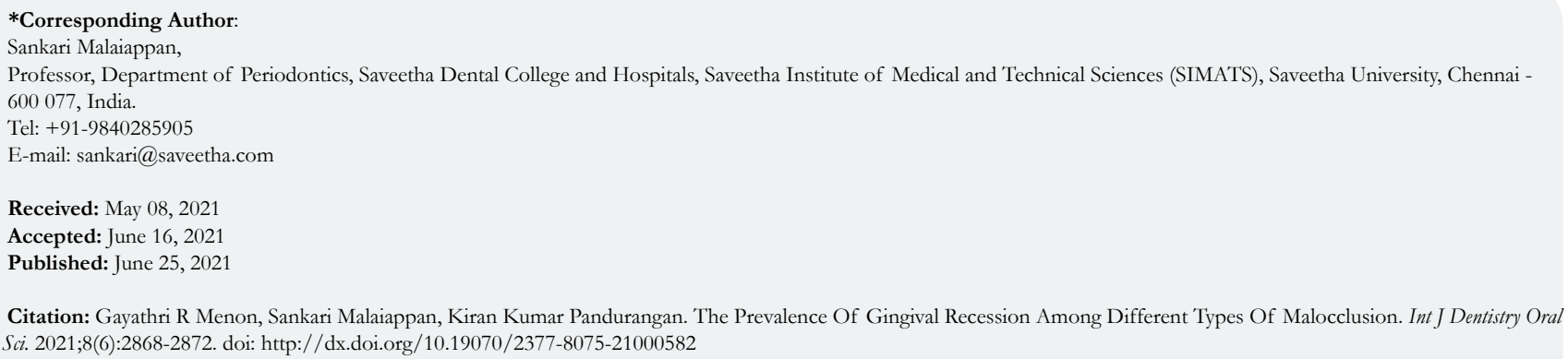

Copyright: Sankari Malaiappan 2021. This is an open-access article distributed under the terms of the Creative Commons Attribution License, which permits unrestricted use, distribution and reproduction in any medium, provided the original author and source are credited. 
difficulty in maintaining oral hygiene, dentin hypersensitivity and increased risk of dental caries [8,9]. The etiology of the conditions is multifactorial and may include tooth malposition, path of eruption, tooth shape, profile and position in arch, alveolar bone dehiscence, muscle attachment and frenal pull,periodontal disease and treatment, orthodontic treatment and other self inflicted injuries $[10,11]$. The most important factor causing increase in gingival recession is thin gingival biotype [12]. The mucogingival complex consists of free gingiva and attached gingiva,mucogingival junction and alveolar mucosa. In an adequate mucogingival complex, the mucogingival tissues have the ability to sustain the biomorphological integrity and can also maintain an enduring attachment to the teeth and the underlying soft tissue, which is always essential. When a mucogingival problem occurs, there are two ways in which it can present itself. Frist, as a close disruption of the mucogingival complex resulting in pocket formation. Second, as an open disruption of the mucogingival complex resulting in gingival clefts and gingival recession [13]. Gingival recession will increase in both prevalence and severity with age. The mandibular incisor region is the most commonly affected region $[14,15]$.

The management for gingival recession is surgical therapy like free graft and pedicle flap are indicated when the gingival recession causes functional or esthetic problems. Coronally displaced flap is a treatment of choice for recession defects [16]. A team has worked on various regenerative therapy that has been indicated for periodontally compromised patients [17-19] and other treatments such as lip repositioning [20]. If the esthetics and function had to be restored dental implants and implant-supported prosthesis can be a predictable treatment modality in periodontal diseases [21]. While performing surgical therapy trauma to the inferior alveolar nerve is one of the complications during surgical procedures in the posterior mandible [22]. Various antimicrobial and chemotherapeutic agents such as chlorhexidine mouth washes , triclosan are employed for the management of periodontitis [23]. Herbal medicines and preparations can also be used for the management of periodontal diseases [24].

As discussed before etiology of gingival recession is multifactorial, one of the reasons for gingival recession is malpositioning of teeth and malocclusion. Normal occlusion of the teeth in their respective arches were considered anatomically and functionally essential for the development and maintenance of a healthy dentition [25]. Several authors have reported that malocclusions and malpositioned teeth are significant factors for the etiology of periodontal disease $[26,27]$. An excessive functional stress can initiate inflammatory changes in the periodontium and thus enhance destructive bacterial processes [28]. Abnormal tooth position may also result in deficient oral hygiene and consequent accumulation of bacterial plaque which maybe lead to periodontal diseases. When any type of malocclusion is diagnosed, the teeth should be aligned to redirect occlusal forces that act along the tooth axis and are harmoniously distributed and rule out occlusal trauma which may affect periodontal health [29, 30]. Previously our team has a rich experience in working on various research projects across multiple disciplines. [31-45]. The aim of the study is to evaluate the prevalence of gingival recession among different types of malocclusion.

\section{Materials And Methods}

This was a retrospective study in which 86000 patients were re- viewed. Data was extracted from patients record, Saveetha Dental College And Hospital, Chennai. The data obtained from the patient's record was from june 2019 to march 2020, out of which 53 patients had both recession and malocclusion. The study included 36 males and 17 females. The data segregation was done based on 1) age 2) gender 3) types of malocclusion, 4) site 5) recession. Based on the age the data was segregated into 3 groups (18-25), (26-30),(31-35),(36-40). Based on the type of malocclusion by angles it was divided into 7 groups; Angles class I, Angles class II, angles class II div 1, Angles class II division 1 subdivision ,Angles class II div 2, Angles class III,Angles class II subdivision. The examination of patients was done using the clinical photographs obtained from patients records and orthodontic and periodontal diagnosis was also evaluated. The data obtained was then tabulated in excel sheet and then transferred to SPSS software for statistical analysis. The software that was used for the statistical analysis was IBM SPSS software version 20. Descriptive statistics were performed and frequencies were found for each variable. Chi square test was the statistical test that was performed to determine the significance.

\section{Results And Discussion}

In the study $67.92 \%$ of males and $32.1 \%$ of females with recession had malocclusion. The most common age group that was affected was $31-35$ years by $39.62 \%$. Recession was most commonly seen in the anterior region by $86.8 \%$. The most common type of malocclusion seen was Angles Class II div 1 by $56.60 \%$. It was found from the chi square test that there is no correlation between type of malocclusion and site of recession with the $p$ value: .444 ( $p>0.05)$. From the chi square test performed to determine the correlation between recession site and gender, it was found that maximum recession was seen in the anterior teeth of male patients. $\mathrm{P}$ value was 0.051 ( $\mathrm{p}<0.05)$, statistically significant.

The aim of the study is to evaluate the prevalence of gingival recession among different types of malocclusion. Mucogingival deficiencies in the anterior teeth especially in the incisors and the development of recession have been related to many etiological factors. Among the various factors predisposing to this condition, malocclusion is of particular interest as improper occlusion can lead to consequent periodontal changes.

In the present study, from the chi square test performed to determine the correlation between recession site and gender, it was found that maximum recession was seen in the anterior teeth of male patients. $\mathrm{P}$ value 0.051 ( $\mathrm{p}<0.05)$, statistically significant. It was found from the study that the gender that was most commonly affected with recession and malocclusion was male by $67.92 \%$. In a study conducted by Jaeahir Ahmad Gani et al., with a concurrent finding it was reported that gingival recession was higher in male by $68.7 \%$ and females by $31.3 \%$. [46]. Similarly in a study conducted it was reported that males were more commonly affected [47]. In a previous study conducted it was reported that the gender affected with gingival recession is male by $68 \%$ [48]. In the present study patients with recession were mostly affected by class II div 1 malocclusion. In a previous study conducted by Estela Santos Gusmão et al., it was reported with a dissimilar finding that $67.8 \%$ of patients with buccally tipped teeth had recession and $67.8 \%$ of patients with maxillary incisors proclination had gingival recession [49]. In another study conducted by Yuri Rodriquez et al., it was reported that $27.5 \%$ of gingival recessions 
Figure 1. Bar graph shows the percentage distribution of patients with recession and malocclusion. $\mathrm{X}$ axis shows the age group of patients and $\mathrm{Y}$ axis shows the percentage of recession patients with malocclusion. 18-25 years age group 20.75\% (blue), 26-30 years age group 22.64\% (green), 31-35 years age group $39.62 \%$ (beige), 36-40 years $16.98 \%$ (yellow). From the graph we can infer that the most common age group with recession and malocclusion was $31-35$ years by $39.62 \%$.

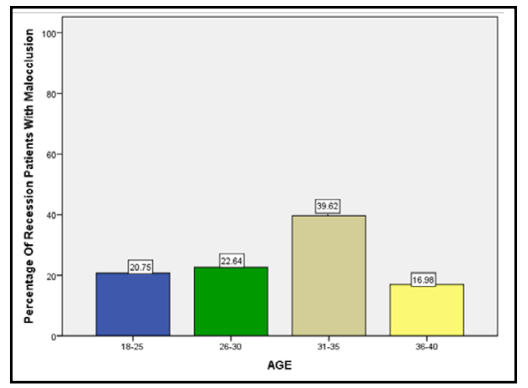

Figure 2. Bar graph shows the percentage distribution of patients with recession and malocclusion. $\mathrm{X}$ axis shows gender and $\mathrm{Y}$ axis shows percentage of recession patients with malocclusion. $67.92 \%$ of patients with recession and malocclusion were male (blue) and $32.08 \%$ of patients were female (green). From the graph we can infer that the most common gender with recession and malocclusion was male by $67.92 \%$.

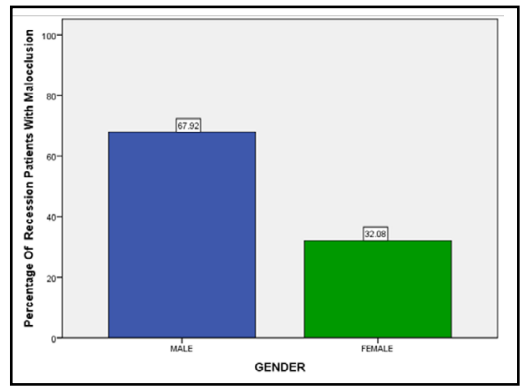

Figure 3. Bar graph shows the percentage distribution of malocclusion in patients with recession. $\mathrm{X}$ axis shows the malocclusion types and $\mathrm{Y}$ axis shows percentage of recession patients with malocclusion. Majority of patients with recession had class II div 1 malocclusion by $56.60 \%$ (beige) and the least number of patients with recession had class II malocclusion by $1.887 \%$ (green). From the figure we can infer that the common type of malocclusion that is prevalent in recession patients is angle's class II div 1 by $56.60 \%$.

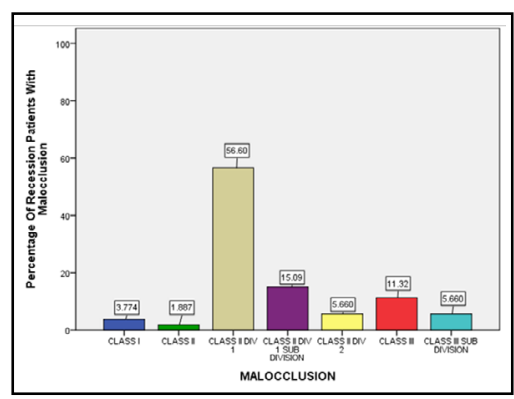

Figure 4. Pie chart shows the percentage distribution of sites at which recession is more prevalent in patients with malocclusion. From the pie chart it is evident that $86.79 \%$ of patients with malocclusion had recession in the anterior teeth (blue) and $13.21 \%$ patients with malocclusion had recession in the posterior teeth (green). From the graph we can infer that the most common site for recession is anterior teeth (86.79\%).

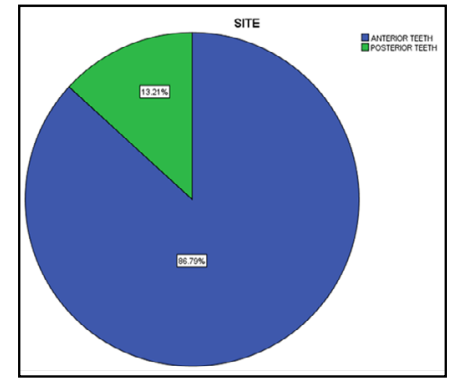

were associated with vestibular inclination movement [50]. The results obtained from the present study shows that the most common age group that was affected was $31-35$ years by $39.62 \%$. In a study conducted by S. Reddy Manchala et al. It was reported with a dissimilar finding that the most common age group in which gingival recession was seen the most is $36-45$ years [48]. In another study conducted it was found that the age group that was affected with recession was above the age of 30 years [47]. In the present study it was found that gingival recession in the anterior region is more prevalent in patients. A study with similar findings reported that gingival recession is present with crowding in the anteriors by $21.2 \%$ and gingival recession is more commonly seen in upper left central incisors by 35.6\% [51]. In another study with a similar finding conducted by Kemal Ustun et.al., it was found that severe gingival recession was present in the mandibular canine and incisors with molar relationship angle's class III [28]. Our institution is passionate about high quality evidence based research and has excelled in various fields [52-62].

The limitation of the study was the limited sample size and it doesn't include the ethinic group. It was a single centered study. The future scope of the study is that a prospective study can be 
Figure 5. Bar graph shows the association between malocclusion classification with sites affected. X axis shows the types of malocclusion and $\mathrm{Y}$ axis shows the number of recession patients with malocclusion. Anterior teeth (blue) and posterior teeth (green). From the graph we can infer that class II div $1(50.94 \%)$ was the type of malocclusion that was prevalent in patients with recession in the anterior teeth. However chi square test shows $\mathrm{p}$ value .444 ( $\mathrm{p}$ $>0.05$ ) was statistically not significant.

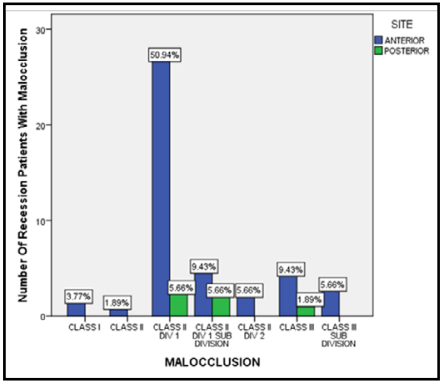

Figure 6. Bar graph shows the association between the site of recession with gender of the study population. $\mathrm{X}$ axis shows the gender of the study population and $\mathrm{Y}$ axis shows the number of recession patients with malocclusion. Anterior teeth (blue ) and posterior teeth (green).From the figure we can infer that male patients had maximum recession in the anterior teeth $(54.72 \%)$. Chi square test shows $\mathrm{p}$ value $.051(\mathrm{p}<0.05)$ was statistically significant.

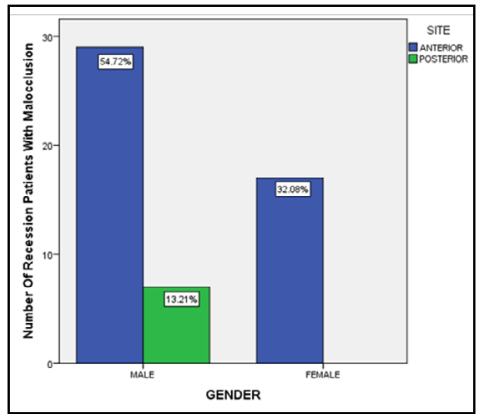

performed with a larger population.

\section{Conclusion}

Based on the present study the most prevalent age group was 31-35years. Male (67.92\%) were more commonly affected than females (32/08\%). Majority of recession patients had class II div 1 malocclusion. Recession was most commonly present in anterior teeth. An association was present between the site of recession and gender of the patients with malocclusion.

\section{Authors Contribution}

Gayathri R Menon, Dr Shankari Malaiappan were the main contributors to the concept, design, literature analysis, workshop discussions, and drafting and revising manuscript. Dr Shankari Malaiappan and Dr Kiran Kumar contributed to drafting and revising manuscripts. All authors gave final approval of the version to be published.

\section{Acknowledgment}

The authors are thankful to the Director of Saveetha Dental College and Hospital, Chennai.

\section{References}

[1]. Priyanka S, Kaarthikeyan G, Nadathur JD, Mohanraj A, Kavarthapu A. Detection of cytomegalovirus, Epstein-Barr virus, and Torque Teno virus in subgingival and atheromatous plaques of cardiac patients with chronic periodontitis. J Indian Soc Periodontol. 2017 Nov-Dec;21(6):456-460.Pubmed PMID: 29551863.

[2]. Varghese SS, Thomas H, Jayakumar ND, Sankari M, Lakshmanan R. Estimation of salivary tumor necrosis factor-alpha in chronic and aggressive periodontitis patients. Contemp Clin Dent. 2015 Sep;6(Suppl 1):S152-6. Pubmed PMID: 26604566
[3]. Mootha A, Malaiappan S, Jayakumar ND, Varghese SS, Toby Thomas J. The Effect of Periodontitis on Expression of Interleukin-21: A Systematic Review. Int J Inflam. 2016;2016:3507503.Pubmed PMID: 26998377.

[4]. Khalid W, Vargheese SS, Lakshmanan R, Sankari M, Jayakumar ND. Role of endothelin-1 in periodontal diseases: A structured review. Indian J Dent Res. 2016 May-Jun;27(3):323-33.Pubmed PMID: 27411664.

[5]. Khalid W, Varghese SS, Sankari M, Jayakumar ND. Comparison of Serum Levels of Endothelin-1 in Chronic Periodontitis Patients Before and After Treatment. J Clin Diagn Res. 2017 Apr;11(4):ZC78-ZC81.Pubmed PMID: 28571268.

[6]. Ramesh A, Varghese SS, Jayakumar ND, Malaiappan S. Chronic obstructive pulmonary disease and periodontitis-unwinding their linking mechanisms. J. Oral Biosci. 2016 Feb 1;58(1):23-6.

[7]. Kassab MM, Cohen RE. The etiology and prevalence of gingival recession. J Am Dent Assoc. 2003 Feb 1;134(2):220-5.

[8]. Orrico SR, Cirelli CC, Rosa FP, Cod JT. Gingival recession in primary dentition: case report. J. Medical Biol. Sci. 2003 Jan 1;2(2):276-82.

[9]. Yared KF, Zenobio EG, Pacheco W. A etiologia multifatorial da recessão periodontal. Rev. Dent. Press Ortodon. Ortop. Facial. 2006 Dec;11(6):45-51.

[10]. Wennström JL. Mucogingival therapy. Ann Periodontol. 1996 Nov; 1 (1):671701.

[11]. Tugnait A, Clerehugh V. Gingival recession-its significance and management. J Dent. 2001 Aug;29(6):381-94.Pubmed PMID: 11520586.

[12]. Müller HP, Eger T, Schorb A. Gingival dimensions after root coverage with free connective tissue grafts. J. Clin. Periodontol. 1998 May;25(5):424-30.

[13]. Löe H, Anerud A, Boysen H. The natural history of periodontal disease in man: prevalence, severity, and extent of gingival recession. J Periodontol. 1992 Jun;63(6):489-95.Pubmed PMID: 1625148

[14]. Albandar JM. Global risk factors and risk indicators for periodontal diseases. Periodontol 2000. 2002 Apr;29(1):177-206.

[15]. Beck JD. Periodontal implications: older adults. Ann. Periodontol. 1996 Nov; 1(1):322-57.

[16]. Thamaraiselvan M, Elavarasu S, Thangakumaran S, Gadagi JS, Arthie T. Comparative clinical evaluation of coronally advanced flap with or without platelet rich fibrin membrane in the treatment of isolated gingival recession. J Indian Soc Periodontol. 2015 Jan;19(1):66.

[17]. Ravi S, Malaiappan S, Varghese S, Jayakumar ND, Prakasam G. Additive Effect of Plasma Rich in Growth Factors With Guided Tissue Regeneration in Treatment of Intrabony Defects in Patients With Chronic Periodontitis: A Split-Mouth Randomized Controlled Clinical Trial. J Periodontol. 2017 Sep;88(9):839-845.Pubmed PMID: 28474968.

[18]. Panda S, Jayakumar ND, Sankari M, Varghese SS, Kumar DS. Platelet rich fibrin and xenograft in treatment of intrabony defect. Contemp Clin Dent. 2014 Oct:5(4):550-4. 
[19]. Avinash K, Malaippan S, Dooraiswamy JN. Methods of Isolation and Characterization of Stem Cells from Different Regions of Oral Cavity Using Markers: A Systematic Review. Int J Stem Cells. 2017 May 30;10(1):12-20. Pubmed PMID: 28531913.

[20]. Ramesh A, Vellayappan R, Ravi S, Gurumoorthy K. Esthetic lip repositioning: A cosmetic approach for correction of gummy smile - A case series. J Indian Soc Periodontol. 2019 May-Jun;23(3):290-294.Pubmed PMID: 31143013.

[21]. Ramesh A, Ravi S, Kaarthikeyan G. Comprehensive rehabilitation using dental implants in generalized aggressive periodontitis. J Indian Soc Periodontol. 2017 Mar;21(2):160-3.

[22]. Kavarthapu A, Thamaraiselvan M. Assessing the variation in course and position of inferior alveolar nerve among south Indian population: A cone beam computed tomographic study. Indian J Dent Res. 2018 JulAug;29(4):405-409.Pubmed PMID: 30127186.

[23]. Ramamurthy JA, Mg V. Comparison of effect of hiora mouthwash versus chlorhexidine mouthwash in gingivitis patients: a clinical trial. Asian J. Pharm. Clin. Res. 2018;11(7):84

[24]. Ramesh A, Varghese SS, Doraiswamy JN, Malaiappan S. Herbs as an antioxidant arsenal for periodontal diseases. J Intercult Ethnopharmacol. 2016 Jan 27;5(1):92-6.Pubmed PMID: 27069730.

[25]. Geiger AM. Malocclusion as an etiologic factor in periodontal disease: a retrospective essay. Am J Orthod Dentofacial Orthop. 2001 Aug;120(2):112-5. Pubmed PMID: 11500651.

[26]. Abu Alhaija ES, Al-Khateeb SN, Al-Nimri KS. Prevalence of malocclusion in 13-15 year-old North Jordanian school children. Community Dent. Health. 2005 Dec;22(4):266-71. PMID: 16379166.

[27]. Abu Alhaija E, Al-Wahadni A. Relationship between tooth irregularity and periodontal disease in children with regular dental visits. J Clin Pediatr Dent. 2006 Jul 1;30(4):296-8.

[28]. Ustun K, Sari Z, Orucoglu H, Duran I, Hakki SS. Severe gingival recession caused by traumatic occlusion and mucogingival stress: a case report. Eur J Dent. 2008 Apr;2(2):127-33.Pubmed PMID: 19212523.

[29]. Hallmon WW. Occlusal trauma: effect and impact on the periodontium. Ann. Periodontol. 1999 Dec;4(1):102-7.

[30]. Maino BG, Giuliano Maino B, Pagin P. The Spider Screw anchorage system. Skeletal Anchorage in Orthodontic Treatment of Class II Malocclusion. 2015. 47-55.

[31]. Hafeez N. Accessory foramen in the middle cranial fossa. Res J Pharm Technol. 2016 Nov 1;9(11):1880.

[32]. Krishnan RP, Ramani P, Sherlin HJ, Sukumaran G, Ramasubramanian A, Jayaraj G, et al. Surgical Specimen Handover from Operation Theater to Laboratory: A Survey. Ann Maxillofac Surg. 2018 Jul-Dec;8(2):234-238. Pubmed PMID: 30693238

[33]. Somasundaram S, Ravi K, Rajapandian K, Gurunathan D. Fluoride Content of Bottled Drinking Water in Chennai, Tamilnadu. J Clin Diagn Res. 2015 Oct;9(10):ZC32-4.Pubmed PMID: 26557612

[34]. Felicita AS. Orthodontic extrusion of Ellis Class VIII fracture of maxillary lateral incisor - The sling shot method. Saudi Dent J. 2018 Jul;30(3):265269.Pubmed PMID: 29942113.

[35]. Kumar S, Rahman RE. Knowledge, awareness, and practices regarding biomedical waste management among undergraduate dental students. Asian J Pharm Clin Res. 2017;10(8):341.

[36]. Gurunathan D, Shanmugaavel AK. Dental neglect among children in Chennai. J Indian Soc Pedod Prev Dent. 2016 Oct 1;34(4):364.

[37]. Sneha S. Knowledge and awareness regarding antibiotic prophylaxis for infective endocarditis among undergraduate dental students. Asian J. Pharm. Clin. Res. 2016 Oct 1:154-9.

[38]. Dhinesh B, Lalvani JI, Parthasarathy M, Annamalai K. An assessment on performance, emission and combustion characteristics of single cylinder diesel engine powered by Cymbopogon flexuosus biofuel. Energy Convers Manage. 2016 Jun 1;117:466-74.

[39]. Choudhari S, Thenmozhi MS. Occurrence and Importance of Posterior Condylar Foramen. LATERALITY. 2016 Aug 28;8:11-43.

[40]. Paramasivam A, Vijayashree Priyadharsini J, Raghunandhakumar S. N6adenosine methylation (m6A): a promising new molecular target in hypertension and cardiovascular diseases. Hypertens Res. 2020 Feb;43(2):153154.Pubmed PMID: 31578458.

[41]. Wu F, Zhu J, Li G, Wang J, Veeraraghavan VP, Krishna Mohan S, et al. Biologically synthesized green gold nanoparticles from Siberian ginseng induce growth-inhibitory effect on melanoma cells (B16). Artif Cells Nanomed Biotechnol. 2019 Dec;47(1):3297-3305.Pubmed PMID: 31379212.

[42]. Palati S, Ramani P, Shrelin HJ, Sukumaran G, Ramasubramanian A, Don $\mathrm{KR}$, et al. Knowledge, Attitude and practice survey on the perspective of oral lesions and dental health in geriatric patients residing in old age homes.
Indian J Dent Res. 2020 Jan-Feb;31(1):22-25.Pubmed PMID: 32246676.

[43]. Saravanan M, Arokiyaraj S, Lakshmi T, Pugazhendhi A. Synthesis of silver nanoparticles from Phenerochaete chrysosporium (MTCC-787) and their antibacterial activity against human pathogenic bacteria. Microb Pathog. 2018 Apr;117:68-72.Pubmed PMID: 29427709.

[44]. Govindaraju L, Gurunathan D. Effectiveness of Chewable Tooth Brush in Children-A Prospective Clinical Study. J Clin Diagn Res. 2017 Mar;11(3):ZC31-ZC34.Pubmed PMID: 28511505.

[45]. Vijayakumar Jain S, Muthusekhar MR, Baig MF, Senthilnathan P, Loganathan S, Abdul Wahab PU, et al. Evaluation of Three-Dimensional Changes in Pharyngeal Airway Following Isolated Lefort One Osteotomy for the Correction of Vertical Maxillary Excess: A Prospective Study. J Maxillofac Oral Surg. 2019 Mar;18(1):139-146.Pubmed PMID: 30728705.

[46]. Ganai JA, Jan SM, Behal R, Naz F. Evaluation of prevalence and predisposing factors of gingival recession in non-professional college students in pulwama district, Jammu \& Kashmir: A cross-sectional study.2019.

[47]. Susin C, Haas AN, Oppermann RV, Haugejorden O, Albandar JM. Gingival recession: epidemiology and risk indicators in a representative urban Brazilian population. J. Periodontol.. 2004 Oct;75(10):1377-86.

[48]. Manchala SR, Vandana KL, Mandalapu NB, Mannem S, Dwarakanath CD. Epidemiology of gingival recession and risk indicators in dental hospital population of Bhimavaram. J Int Soc Prev Community Dent. 2012 Jul;2(2):69-74.Pubmed PMID: 24478971.

[49]. Gusmão ES, Queiroz RD, Coelho RD, Cimóes R, Santos RL. Relationship between malpositioned teeth and the condition of periodontal tissues. Dental Press J Orthod. 2011 Aug;16(4):87-94.

[50]. Rodríguez YC, Pomarino SG. Orthodontic dental movement and its association with the presence of gingival recession. Revista odontológica mexicana. 2017 Jan 1;21(1):e8-11.

[51]. Eid HE. Prevalence of anterior gingival recession and related factors among Saudi adolescent males in Abha City, Aseer Region, Saudi Arabia. J Oral Res Rev. 2014 Jan 1;1(1):18

[52]. Vijayashree Priyadharsini J. In silico validation of the non-antibiotic drugs acetaminophen and ibuprofen as antibacterial agents against red complex pathogens. J Periodontol. 2019 Dec;90(12):1441-1448.Pubmed PMID: 31257588.

[53]. PC J, Marimuthu T, Devadoss P, Kumar SM. Prevalence and measurement of anterior loop of the mandibular canal using CBCT: A cross sectional study. Clin Implant Dent Relat Res. 2018 Apr 6;20(4):531-4.

[54]. Ramesh A, Varghese S, Jayakumar ND, Malaiappan S. Comparative estimation of sulfiredoxin levels between chronic periodontitis and healthy patients - A case-control study. J Periodontol. 2018 Oct;89(10):1241-1248.Pubmed PMID: 30044495.

[55]. Ramadurai N, Gurunathan D, Samuel AV, Subramanian E, Rodrigues SJ. Effectiveness of $2 \%$ Articaine as an anesthetic agent in children: randomized controlled trialClin. Oral Investig. 2019 Sep;23(9):3543-50.

[56]. Sridharan G, Ramani P, Patankar S, Vijayaraghavan R. Evaluation of salivary metabolomics in oral leukoplakia and oral squamous cell carcinoma. J. Oral Pathol. Med. 2019 Apr;48(4):299-306.

[57]. Ezhilarasan D, Apoorva VS, Ashok Vardhan N. Syzygium cumini extract induced reactive oxygen species-mediated apoptosis in human oral squamous carcinoma cells. J Oral Pathol Med. 2019 Feb;48(2):115-121.Pubmed PMID: 30451321

[58]. Mathew MG, Samuel SR, Soni AJ, Roopa KB. Evaluation of adhesion of Streptococcus mutans, plaque accumulation on zirconia and stainless steel crowns, and surrounding gingival inflammation in primary molars: randomized controlled trial. Clin Oral Investig. 2020 Sep;24(9):1-6.Pubmed PMID: 31955271

[59]. Samuel SR. Can 5-year-olds sensibly self-report the impact of developmental enamel defects on their quality of life? Int J Paediatr Dent. 2021 Mar;31(2):285-286.Pubmed PMID: 32416620.

[60]. R H, Ramani P, Ramanathan A, R JM, S G, Ramasubramanian A, et al. CYP2 C9 polymorphism among patients with oral squamous cell carcinoma and its role in altering the metabolism of benzo[a]pyrene. Oral Surg Oral Med Oral Pathol Oral Radiol. 2020 Sep;130(3):306-312.Pubmed PMID: 32773350 .

[61]. Chandrasekar R, Chandrasekhar S, Sundari KKS, Ravi P. Development and validation of a formula for objective assessment of cervical vertebral bone age. Prog Orthod. 2020 Oct 12;21(1):38.Pubmed PMID: 33043408.

[62]. Vijayashree Priyadharsini J, Smiline Girija AS, Paramasivam A. In silico analysis of virulence genes in an emerging dental pathogen A. baumannii and related species. Arch Oral Biol. 2018 Oct;94:93-98.Pubmed PMID: 30015217. 